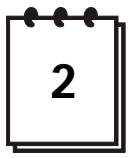

\title{
Peran Perguruan Tinggi Mewujudkan Dinamika Kedamaian dalam Kehidupan Masyarakat
}

\author{
Sumardjo dan Aman Wirakartakusumah ${ }^{1}$
}

\begin{abstract}
In any civilization, peacefulness or non-violence culture could be the ultimate end of human life. It contains human right principles to be achieved by community, civics, and nation. Albeit, in reality, the situation achieved is diametrically in the opposite to what expected where competition, contravention and social conflict arises very sharply unless a constructive conflict management is applied. The potentiality of social conflict to occur may be reduced to a tolerable rate when constructive dialogues can be built. The dialogues should be able to facilitate the development of convergence communication and the actualization of equality principles. Higher education processes will be one the most important institutions that could bring the actualization of the principles of peacefulness into reality. This could be true when education could assure the effectiveness of value transformation processes throughout generations. The role of high education institutions to make non-violence culture to become apparent is essential. The dynamic life in a peaceful culture can only be realized when a situation of welfare, equality and well expression of communication behavior are well maintained in the community life.
\end{abstract}

Keywords: non-violence culture, peacefulness, higher education, communication

\section{Potensi Ancaman terhadap Terwujudnya Perdamaian}

Kedamaian merupakan dambaan kehidupan setiap manusia, namun seberapa jauh perdamian itu secara sadar diupayakan terwujudnya? Hal ini masih menjadi pertanyaan mendasar dalam kehidupan berbangsa maupun bermasyarakat yang masih kurang terjawab. Banyak orang mendambakan kedamaian, namun potensi konflik tidak terkelola dengan baik dan terjadi di banyak tempat, seperti peperangan, perang antar kelompok agama, konflik sosial, politik, maupun ekonomi, bahkan terorisme sebagai salah satu muara dari potensi konflik masih terus terjadi. Provokator muncul seolah sebagai dewa penolong bagi pihak yang termarjinalkan, namun tidak sedikit terdiri dari pihak yang sebenarnya lebih mengutamakan kepentingan diri sendiri dengan memanfaatkan kesenjangan dan potensi konflik yang ada. Situasi kesenjangan antar lapisan dan antar golongan yang banyak terjadi merupakan suasana yang kondusif bagi pihak tertentu (vested interest) melakukan aktivitas yang dapat merusak kedamaian kehidupan bermasyarakat dan berbangsa. Hal ini dapat dipicu oleh kesenjangan dalam informasi dan langkanya konvergensi dalam komunikasi sosial dalam kehidupan masyarakat tersebut.

Partisipasi sosial merupakan salah satu kata kunci dalam terwujudnya keadilan dan kesenjangan melalui dialog yang efektif mewujudkan konvergensi komunikasi di

${ }^{1}$ Guru besar penyuluhan pembangunan Fakultas Ekologi Manusia IPB 
antara pihak yang berinteraksi dalam memenuhi kebutuhan hidupnya masing-masing (Sumardjo et al, 2004; Sumardjo, 2008). Partisipasi menghasilkan kolaborasi, kemitraan dan integrasi sosial yang kondusif bagi terwujudnya sinergi kehidupan bermasyarakat (win-win situation).

Pada kehidupan masyarakat yang kompleks dengan latar belakang keragaman budaya/ etnis, kepercayaan/agama, strata, profesi dan golongan seperti di Indonesia, dibutuhkan suatu upaya khusus untuk terwujudnya suatu kedamaian dalam kehidupan. Hal ini disebabkan keragaman-keragaman tersebut bila tidak disikapi dengan arif berpotensi besar menjadi potensi konflik yang berkepanjangan dan dapat muncul dalam wujud permusuhan dan peperangan. Upaya-upaya untuk mewujudkan kedamaian yang hakiki dalam kehidupan masyarakat maupun suatu bangsa tersebut dapat ditempuh melalui berkembangnya kearifan lokal (local wisdom) sebagai upaya bermasyarakat maupun berbangsa, namun yang juga tidak kalah pentingnya adalah melalui upaya pendidikan, baik formal, non formal, maupun informal, yang mengandung muatan nilai kearifan. Tulisan ini membahas tentang bagaimana peran pendidikan, khususnya pendidikan tinggi dalam berkontribusi bagi terwujudnya kedamaian (peaceful) dalam kehidupan bermasyarakat, berbangsa, bahkan antar bangsa tersebut.

Negara-negara dengan berbagai keragaman budaya, agama, dan keragaman latar belakang kehidupan seperti itu, antara lain dapat ditemukan di negara-negara dunia ketiga seperti Indonesia dan kawasan Asia Tenggara lainnya, maupun di negaranegara maju, seperti Jepang, Amerika, maupun Eropa. Tulisan ini diangkat dari pengalaman di Indonesia, yang akhir-akhir ini tengah berupaya mengatasi berbagai ancaman yang bersumber dari keragaman latar belakang kehidupan tersebut. Bahkan salah satu ancaman terbesar adalah terjadinya disintegrasi bangsa dan terorisme, yang dalam kurun waktu lima tahun terakhir ini secara berangsur relatif dapat diatasi. Keadaan tersebut semakin kondusif dalam suasana lemahnya penghayatan atas nilai ideal (ideal value) sehingga terjadilah kesenjangan antara nilai ideal dengan nilai aktual (actual value). Kondisi ini menyebabkan daya saring (filter system) individu menjadi lemah, sehingga relatif mudah terprovokasi kearah perilaku disintegratif, yang menyebabkan erosi terhadap terwujudnya kedamaian. Pemicu keadaan ini antara lain adalah lemahnya sistem pendidikan mengembangan sistem nilai ideal secara efektif.

\section{Suasana Damai Didambakan Manusia dalam Setiap Kehidupannya}

Dinamika kedamaian (peaceful) adalah suatu keadaan dinamis namun tidak ada kerusuhan, tenang, tenteram dan rukun tidak terjadi peperangan atau permusuhan (conflict). Pada kenyataan, kedamaian merupakan suatu kondisi yang didambakan oleh banyak manusia dalam kehidupannya, namun perilaku yang merusak kedamaian itu banyak yang justru terjadi, bahkan dalam rangka mewujudkan kedamaian itu sendiri, namun mengabaikan sinergi. Pendekatan kolaborasi mulai popular tahun 1980-an (Trist, 1989) dan makin berkembang pada awal abad 21 (Straus, 2002) dikenal sebagai pendekatan yang bukan bersifat permusuhan (nonadversarial approach) untuk penyelesaian problem dan penyelesaian konflik.

Konsep kedamaian dalam kamus ilmu-ilmu sosial tidak banyak dibahas, sehingga sulit ditemukan penjelasannya. Sebaliknya istilah konflik sangat banyak dibahas dalam berbagai ilmu, baik sosiologi, manajemen, maupun politik. Apakah itu pula 
yang menyebabkan kelangkaan program pendidikan yang mengulas dan menjadikan konsep 'perdamaian' sebagai suatu bagian dari kurikulum, maupun program non kurikuler. Dalam kondisi seperti ini tampaknya dalam konsep pendidikan nilai kedamaian yang dinamis dapat menjadi salah satu solusi persoalan konflik sosial yang dapat merugikan masyarakat menjadi potensi konflik yang terkelola dengan arif dalam mewujudkan kesejahteraan.

Uraian ini mencoba merumuskan suatu kondisi damai, yaitu suatu suasana kehidupan yang didalamnya mengandung makna berdaya dan komunikatif, berkeamanan, berkerukunan, berketenteraman, berkeadilan, dan berdaulat atau mandiri yang selalu bermuara pada terwujudnya martabat dan kesejahteraan. Suatu kondisi kehidupan masyarakat atau bangsa dikatakan damai manakala suatu kehidupan mengalami keadaan cenderung terbebas dari rasa khawatir, terbebas dari ancaman bahaya, terbebas dari konflik/ sikap permusuhan, terbebas dari tekanan dominasi atau penindasan, sehingga bernuansa suasana konvergensi komunikatif, kolaboratif yang berkeadilan, serta kemitraan yang sinergis.

Secara sosiologis versi Gillin dan Gillin (Selo Soemardjan, 1964: 501), perdamaian (processes of association) dan konflik sosial (processes of dissociation) dapat diibaratkan dua sisi dari sebuah mata uang. Manakala potensi konflik tidak terkelola maka berbagai ancaman dan kekhawatiran muncul sebagai fenomena sosial yang mengemuka dalam suatu kehidupan manusia. Di sisi lain, belum banyak pihak dalam kehidupan masyarakat yang peduli terhadap upaya pengelolaan konflik secara sadar dan terencana, bahkan sekalipun di dunia pendidikan implementasinya masih merupakan kelangkaan.

Ada kesan, pengelolaan potensi konflik merupakan sebuah ancaman namun tabu untuk dibicarakan. Pada hal realitasnya, kemampuan mengelola konflik sosial dan terwujudnya kedamaian menjadi kebutuhan riil bagi kehidupan bermasyarakat dan berbangsa. Akibatnya terjadi keterlambatan dalam upaya preventif atau pencegahan terjadinya permusuhan yang berdampak pada situasi yang sangat merugikan bagi kehidupan manusia. Kecuali dalam konteks manajemen organisasi, masih sangat langka program pengelolaan potensi konflik ini ditemukan secara meluas, terbuka dan transparan, baik dalam kehidupan bermasyarakat, bisnis maupun dunia pendidikan. Meskipun sebenarnya sudah ada metoda-metoda pengelolaan konflik dan kolaborasi dikembangkan, namun belum dikembangkan secara meluas, bahkan kepada pihak yang sering dihadapkan pada situasi konflik, seperti di sekitar operasional perusahaan yang mengekslorasi sumberdaya alam. Tulisan ini mencoba berkontribusi dalam upaya membuka permasalahan upaya untuk mewujudkan perdamaian, khususnya melalui dunia pendidikan.

\section{Beberapa Kasus : Potensi Konflik versus Kedamaian}

Keragaman suku bangsa, etnis, agama, strata sosial, profesi dan golongan merupakan basis munculnya ekspresi perilaku yang mengarah pada potensi konflik, kompetisi, dan konflik terbuka. Hal ini diangkat dari pengalaman penulis berdasarkan berbagai pengalaman dalam melakukan kajian tentang resolusi konflik dan praktek-praktek pemberdayaan masyarakat, khususnya di pedesaan, pertanian dan masyarakat pesisir, maupun masyarakat semi urban dan urban. Gambaran secara rinci dapat dilihat pada Tabel 1. 
Tabel 1 Potensi Konflik dan Alternatif Resolusi Konflik (Kedamaian)

\begin{tabular}{|l|l|l|l|}
\hline $\begin{array}{l}\text { Latar Belakang } \\
\text { Interaksi sosial }\end{array}$ & $\begin{array}{l}\text { Ekspresi } \\
\text { Perilaku }\end{array}$ & Potensi konflik & $\begin{array}{l}\text { Resolusi Konflik } \\
\text { (Kedamaian) }\end{array}$ \\
\hline $\begin{array}{l}\text { Multi Agama } \\
\text { kepercayaan }\end{array}$ & $\begin{array}{l}\text { Keragaman } \\
\text { Pengamalan }\end{array}$ & Keyakinan dan Nilai & $\begin{array}{l}\text { Toleransi/ akulturasi/ } \\
\text { asimilasi }\end{array}$ \\
\hline $\begin{array}{l}\text { Keragaman } \\
\text { Bangsa }\end{array}$ & $\begin{array}{l}\text { Sikap Super/ } \\
\text { inferiority }\end{array}$ & Dominasi, arogansi & $\begin{array}{l}\text { Intercultural } \\
\text { Communication }\end{array}$ \\
\hline Multi etnis & $\begin{array}{l}\text { Keragaman } \\
\text { budaya } \\
\text { (Steriotype })\end{array}$ & $\begin{array}{l}\text { Nilai, Bahasa dan } \\
\text { perilaku } \\
\text { (Etnosentrisme })\end{array}$ & $\begin{array}{l}\text { Cross } \text { cultural } \\
\text { Communication } \\
\text {-akulturasi/asimilasi }\end{array}$ \\
\hline Multi strata & $\begin{array}{l}\text { Keragaman } \\
\text { kemampuan }\end{array}$ & $\begin{array}{l}\text { Dominasi / } \\
\text { subordinasi }\end{array}$ & Kemitraan/ Kolaborasi \\
\hline Multi profesi & $\begin{array}{l}\text { Keragaman } \\
\text { kompetensi }\end{array}$ & $\begin{array}{l}\text { Kompetisi profesi/ } \\
\text { sumberdaya }\end{array}$ & Kemitraan koordinasi \\
\hline Multi golongan & $\begin{array}{l}\text { Keragaman } \\
\text { kebutuhan }\end{array}$ & Konflik kepentingan & $\begin{array}{l}\text { Kemitraan/Kolaborasi/ } \\
\text { Integrasi Struktur }\end{array}$ \\
\hline
\end{tabular}

Pada Tabel 1 secara ringkas digambarkan latar belakang interaksi sosial yang berpotensi menjadi sumber konflik, yang terekspresikan dalam berbagai bentuk perilaku kehidupan manusia. Ekspresi perilaku tersebut berpotensi menjadi sumber konflik yang berakar pada ekspresi perilaku dan latar belakang interaksi sosial diantara para pelaku dengan keragaman latar belakang yang cukup komplek. Berdasarkan pengalaman dapat diangkat alternatif resolusi konflik yang merupakan upaya untuk mewujudkan kedamaian dalam kehidupan antar manusia.

Keragaman agama berpotensi menimbulkan kelompok penganut keagamaan yang mayoritas dan minoritas. Interaksi keduanya bila tidak terkelola dengan tepat dan memadai berpotensi timbul konflik sosial horizontal. Kasus konflik sosial di Poso maupun di Ambon pada menjelang dan awal abad 21, merupakan contoh konkrit timbul karena faktor dominasi pihak tertentu terhadap pihak lain dalam kehidupan beragama. Kasus lain dapat ditemukan konflik sosial antar pemeluk agama yang sama juga berpotensi terjadi dalam kehidupan, misalnya kasus pengurasakan tempat ibadah antar penganut aliran agama tertentu di Kota Bandung yang terjadi awal abad 21 ini. Fenomena itu terjadi tampaknya karena kelangkaan terjadinya komunikasi yang konvergen, mengingat masing-masing yang berkonflik sama-sama mengamalkan keyakinannya dalam beribadah melalui agama yang bernilai luhur.

Hasil kajian di sebelas kampus perguruan tinggi negeri maupun swasta di beberapa wilayah Indonesia (Sumardjo dkk, 2005), ditemukan adanya kelompok-kelompok keagamaan yang juga berpotensi menjadi sumber konflik. Kasus perkelahian antar mahasiswa di Makasar pada awal abad 21 juga tidak jarang berakar dari masalah kelompok keagamaan seperti itu, namun berbaju kompetisi kedudukan dalam kelembagaan kemahasiswaan atau bentuk yang lebih sederhana lainnya. Sebaliknya, pada kebanyakan perguruan tinggi potensi konflik semacam itu dapat dikelola secara efektif sehingga tidak mengemuka menjadi permusuhan antar mahasiswa. Perguruan tinggi yang menerapkan sistem nilai kehidupan kampus dan akademis secara tegas dan konsisten, seperti di Bogor, dalam penegakan norma dan sanksi, serta menempatkan kampus sebagai ruang yang netral dari intervensi kepentingan 
pihak luar ternyata efektif mengendalikan potensi konflik menjadi kolaborasi yang kondusif bagi kedamaian dalam kehidupan kampus maupun antar kampus. Kampus semestinyalah menjadi tempat menanamkan nilai-nilai luhur yang akan diamalkan dalam kehidupan semasa maupun setelah mahasiswanya lulus dan terjun di masyarakat luas. Seberapa jauh nilai-nilai luhur soft-skill semacam itu mengimbangi kemampuan berfikir dan bernalar berbasis hard-science yang banyak digali selama belajar di perkuliahan? Jawabannya, masih terjadi kesenjangan yang dapat berdampak pada kesenjangan implementasi antara nilai ideal kehidupan dengan nilai aktualnya, yang lebih memprihatinkan lagi apabila nilai idealnya sendiri masih tidak jelas. Barangkali itu yang dikhawatirkan di medio tahun tujuh puluhan menjelang tahun delapan puluhan ketika kampus terjadi perubahan dalam kelembagaan mahasiswa dari dewan mahasiswa menjadi keluarga mahasiswa yang dipelopori oleh Menteri Pendidikan dan Kebudayaan saat itu.

Konsep asrama mahasiswa tingkat pertama di kampus dengan konsep multi budaya yang diterapkan di kampus IPB pada awal abad 21, cukup efektif meredam dan mengelola potensi konflfk antar etnis maupun antar agama. Keragaman etnis antar mahasiswa dari berbagai daerah di Indonesia berpotensi menimbulkan potensi steriotype dan etnosentrisme muncul ke permukaan dalam bentuk riak-riak kecil, yaitu menganggap nilai dan tradisi etnisnya yang terbaik dibanding etns lain. Di masa lalu, pada masa penjajahan belanda, sikap etnosentrisme ini tampaknya dikelola dan direkayasa sedemikian rupa, sehingga efektif untuk menerapkan politik adu domba (devide et impera). Kecurigaan antar etnis menguat bahkan ketika antar etnis tersebut belum berinteraksi. Keberadaan asrama dengan program multi-budaya seperti yang dikembangkan oleh IPB berpotensi melemahkan sikap-sikap etnosentrisme tersebut untuk tidak berkembang, sebaliknya terjadi akulturasi bahkan asimilasi antar mahasiswa yang berbeda etnis dan budaya. Hasil program multi budaya tersebut adalah terwujudnya kedamaian mewarnai suasana kehidupan kampus, ditandai semakin menghilangnya perkelaian antar mahasiswa dari fakultas yang berbeda.

Potensi konflik dapat bersumber dari kompetisi antar pihak dengan kemampuan dan kompetensi yang berbeda, baik itu dalam kehidupan kampus maupun pada masyarakat di luar kampus. Potensi konflik semacam ini dapat dikelola secara efektif melalui ajang kompetisi sehat seperti Pekan Ilmiah Mahasiswa Nasional (PIMNAS) dengan aturan main yang jelas dan adil (fearness) berdampak tidak terjadi permusuhan di antara mahasiswa sebagai pihak yang berkompetisi baik dalam prestasi (ability) maupun dalam bidang keprofesiannya. Potensi konflik yang laten di antara mahasiswa inter maupun antar perguruan tinggi menjadi terbuka dan relatif menjadi lebih mudah dikelola secara efektif, dengan indikasi melemahnya intensitas permusuhan di kalangan mahasiswa. Dari pengalaman mendapat tugas dalam bidang pengembangan kemahasiswaan di awal tahun 2000an, dapat diungkapkan terjadinya sedikit kasus permusuhan di antara mahasiswa biasanya terjadi pada mahasiswa yang tidak memiliki interes atau prestasi akademik yang tinggi, baik intrakurikuler maupun ekstra kurikuler, atau bahkan tidak punya dasar kompetensi beladiri yang memadai.

Berbagai golongan di luar kampus, baik itu berupa organisasi massa keagamaan maupun organisasi partai politik sangat intensif berusaha melakukan kaderisasi 
kepada para mahasiswa sebagai kader organisasinya. Ketegasan dan kebijakan bahwa kampus merupakan ruang berdaulat, bebas intervensi dan aktivitas keormasan ekstra universiter dan kepartaian ternyata sedikit banyak menjadi efektif untuk mengelola kehidupan kampus menjadi media interaksi pembelajaran yang damai dan kondusif.

Keikutsertaan seseorang dalam intervensi golongan tertentu dalam kehidupan di dalam kampus ternyata berpotensi untuk mengkotak-kotakkan mahasiswa dalam kelompok atau golongan tertentu. Pengkotaan ini menyebabkan wawasan mahasiswa menjadi sempit sesempit wawasan golongan yang merasukinya. Hal ini menyebabkan seorang mahasiswa tidak tertarik untuk memahami kehidupan golongan lain di luar kelompoknya, karena terjebak dengan kaca mata kuda yang dibentuk oleh organisasi massa pembinanya. Perguruan tinggi tidak perlu melarang seseorang untuk mengikuti aktivitas atau kaderisasi partai atau golongan organisasi massa tertentu sepanjang hal itu dilakukan di luar kampus, namun tidak dibenarkan aktivitas partai atau golongan tertentu masuk ke dalam kehidupan di dalam kampus. Pada tahun 1977/1978 aktivitas akibat intervensi pihak luar ke dalam kehidupan kampus menimbulkan permusuhan antar mahasiswa dari kader golongan atau partai yang berbeda dan melakukan aktivitas di dalam kampus, yang membuat suasana kampus tidak damai atau tidak kondusif sebagai media belajar mahasiswa.

\section{Kearifan Lokal (Local Wisdom) sebagai Wujud Upaya Menuju Kedamaian}

Pada kehidupan masyarakat yang sudah mentradisi ditemukan kearifan lokalkearifan lokal yang mengandung unsur budaya (culture) damai atau nilai (value) kedamaian dapat digali sebagai sumber nilai unggul bangsa. Tradisi kedamaian itu dapat dikenali melalui peribahasa yang di masa lalu disosialisasikan antar generasi dalam keluarga (informal education) maupun melalui pendidikan formal. Generasi muda mewarisi nilai-nilai kearifan yang tersirat dalam banyak peribahasa dan proses budaya sejenisnya.

Beberapa contoh kearifan berikut dapat dikemukakan dan digali dalam beberapa peribahasa atau kata-kata bijak berikut yang mengandung nilai kedamaian. Dalam bahasa melayu dikenal "lain lubuk lain ikannya, lain ladang lain belalangnya" yang mengandung makna dan nilai "empati" bahwa setiap orang perlu memahami bahwa di setiap daerah atau masyarakat berbeda budaya dan cita-rasanya yang perlu dipahami. Empati semacam ini merupakan nilai utama dalam berkomunikasi secara asertif, efektif, santun dan beradab. Contoh lainnya "Dimana bumi dipijak di situ langit dijunjung" yang tersirat makna dan nilai "adaptasi". Dimana pun seseorang berada di situ ada nilai kearifan dan norma yang berlaku serta dihargai atau diamalkan, maka dapat dipastikan akan terwujud kedamaian dalam berinteraksi sosial.

Banyak kata-kata bijak yang dapat ditemukan di bumi nusantara ini yang kemudian sejalan dan selaras dengan pemikiran di era modern, dapat ditemukan pada contohcontoh berikut. "Menang tanpa ngasorake" kata bijak dalam bahasa Jawa ini merupakan warisan Sultan Paku Buono dari Mataram yang bermakna dan mengandung nilai "win-win situation" yang dikemukakan oleh Covey (1993) dalam bukunya "The Seven Habit of Highly Effective People" yang merupakan best seller di era menjelang abad 21. Contoh lain, "Ojo dumeh" dan "Ojo ngaji mumpung" merupakan kata bijak yang tersirat makna dan nilai tentang etos kerja yang tinggi 
dan perilaku profesional perlu dijunjung dan menghindari sikap dominasi ketika sedang berada dalam tampuk kekuasaan atau dalam posisi "di atas" dan harus menghindari berbuat di luar kewenangannya. "Sepi ing pamrih, rame ing gawe" tersirat makna dan nilai gotong royong dan mengutamakan kerjasama kemitraan yang berkelanjutan dalam keselarasan, keserasian dan kedamaian yang berkeadilan.

Pandangan seperti itu terkesan mencampuradukkan antara perspektif teori konflik dengan perspektif teori fungsional Parsonian dan penerus-penerusnya. Dengan kata lain analisis ini tidak memihak pada pilar teori yang jelas, sebaliknya itulah pilar yang diacu, yaitu pilar kolaborasi. Kedua perspektif pilar teori sebaiknya dipahami dengan baik untuk dapat menggunakan pilar kolaborasi ini.

Banyak contoh-contoh kearifan lokal dalam kata-kata bijak peribahasa Indonesia/ Nusantara yang dapat digali dan disosialisasikan pada generasi muda. Kata-kata bijak tersebut akhir-akhir ini hampir tidak mendapat tempat dalam dunia pendidikan maupun dalam proses pewarisan nilai dalam pendidikan keluarga maupun masyarakat. Implikasi dari uraian ini adalah perlunya mengangkat dan menyediakan tempat kearifan lokal yang termuat dalam kata-kata bijak tersebut dalam dunia pendidikan formal, non formal, maupun informal, melalui sekolah, bentuk-bentuk praktek penyuluhan dan komunikasi pembangunan, melalui media komunikasi massa maupun lingkungan keluarga dan masyarakat. Perspektif pilar teori kolaborasi mendapatkan momentumnya dalam kondisi yang demikian itu. Program studi Ilmu Peyuluhan Pebangunan dan Program Studi Komunikasi Pembangunan yang telah cukup lama di IPB sejak awal tahun 1980an tampaknya sama-sama kondusif untuk berkembangnya teori kolaborasi ini.

\section{Kedamaian pada Tataran Teori: Teori Konflik versus Fungsional}

Pada tataran teori dikenal luas ada dua teori besar yang melihat persoalan kedamaian tersebut dari dua perspektif, yaitu teori fungsional yang lahir lebih dahulu dan dikritik oleh teori konflik yang lahir kemudian. Di satu sisi Teori Fungsional dipelopori oleh Talkot Parsons yang mengutamakan keselarasan, keserasian dan keharmonisan dalam mewujudkan kedamaian dan di sisi lain, Teori Konflik yang dipelopori oleh Mark yang melihat interaksi sosial dari perspektif dialogis tesa anti tesa dan sintesa. Perdebatan keduanya sampai sekarang dinilai masih relevan meskipun sudah ada arah terjadi titik temu pada posisi moderat (ditengah-tengah) seperti yang dikemukan oleh Dahrendorf (Henslin, 2007). Yang terakhir ini menginspirasi berkembangnya perspektif pemikiran Kolaboratif dalam interaksi sosial ke depan, khususnya dalam bidang ilmu-ilmu komunikasi pembangunan dan penyuluhan pembangunan.

Teori Funsional yang dipelopori oleh Talkot Parsons pada dasarnya mengangkat suatu perubahan sosial sebagai wujud perkembangan suatu masyarakat itu dilaksanakan melalui nilai kehidupan yang damai, selaras, kasih sayang dan berkelanjutan. Setiap kedudukan berfungsi masing-masing layaknya organ manusia dan apabila ada organ yang kurang berfungsi maka dalam bagian tersebut perlu direhabilitasi agar berfungsi sebagaimana mestinya.

Teori Konflik kontemporer pada dasarnya melihat bahwa setiap masyarakat atau kehidupan antar manusia, karena sifat dasarnya selalu terkandung potensi konflik, baik itu pada tataran individu maupun pada tataran kelompok, organisasi maupun 
kehidupan bermasyarakat dan antar bangsa. Potensi konflik tidak dapat dihilangkan tetapi dapat dikelola hingga tidak berkembang berada pada taraf permusuhan atau konflik terbuka. Oleh karena itu dalam organisasi atau kehidupan berkelompok dikenal teori atau konsep manajemen konflik, yaitu suatu upaya agar potensi konflik terkelola, sehingga menjadi perubahan sosial yang berkembang secara berkeadilan. Pada keadaan itulah kedamaian dan kesejahteraan yang adil itu sebenarnya terwujud secara dinamis dalam bentuk interaksi sosial dan kehidupan yang bermartabat, melalui pola-pola komunikasi yang konvergen (Sumardjo, 1999; Sumardjo, 2008).

Fakta implementasi kedua teori tersebut dapat dilihat bahwa pada era pemerintahan orde baru yang cenderung menerapkan paradigma dominan teori fungsional strukturalism Parsonian dalam perspektif Teori Modernisasi. Di era reformasi dan yang telah menjadi nafas reformasi adalah nuansa Teori Konflik dalam kemasan Teori Ketergantungan, yaitu melepaskan diri kehidupan bangsa ini dari ketergantungan dan dominasi negara kuat atau negara maju. Polemik kedua paradigma tersebut akhir-akhir ini mengemuka dalam bentuk euforia konflik, demo dan permusuhan antar pihak tertentu yang pada dasarnya merupakan bentuk-bentuk manifestasi konflik yang tak terkelola secara efektif (Sumardjo, 2007; Sumardjo, 2008).

Peran dunia pendidikan formal dalam hal ini adalah mendudukan dan menumbuhkan proses penyadaran pada para anak didik tentang wawasan kedua atau keempat teori tersebut. Hal ini dimaksudkan agar masyarakat melalui anak didik dan kiprah pendidiknya mampu menerapkan wawasan teori-teori tersebut secara proporsional. Keempat teori yang dimaksud adalah Teori Fungsional dengan turunannya paradigma dominan Teori Modernisasi dan Teori Konflik dengan turunan paradigma dominan teori kritis yaitu Teori Ketergantungan. Keempat teori tersebut tampaknya perlu dimasukkan dalam silabus kurikulum pembelajaran dalam pendidikan formal di sekolah maupun di perguruan tinggi.

Fakta menunjukkan, di masa lalu Teori Konflik dihindari untuk dipelajari dan kenyataannya melalui kelemahan pemahaman perpektif Teori Konflik inilah terjadi subordinasi masyarakat secara sistematis. Ungkapan senada pernah diutarakan oleh Paulo Freire seorang guru besar filsafat pendidikan dari Brazil yang mengungkapkan perspektif kritis Teori Penyadaran. Karena pemikirannya seperti itu Freire dipenjarakan oleh pemerintah jajahan Potugis di Brazil, namun hal yang sama mendapat award dari Pemerintah Amerika.

\section{Peranan Masyarakat dalam Upaya Mewujudkan Kehidupan Damai}

Bercermin dari pengalaman di masa lalu yang terjadi di Nusantara ini, maka perlu dirumuskan alternatif bagaimana mewujudkan kedamaian di dalam kehidupan berbangsa maupun bernegara. Berdasarkan analisis singkat antara paradigma dominan perspektif teori fungsional (Parsons) dan teori konflik (Mark) dan perspektif garis tengah Dahrendorf, maka wawasan kedua paradigma teori dan turunannya perlu dipahami oleh masyarakat dalam mewujudkan kedamaian dinamis kehidupannya.

Jiwa dari teori konflik adalah dialog, thesa-antithesa-synthesa diangkat sebagai kekuatan untuk berubah dan berkembang secara dinamis dan berkeadilan dikombinasikan dengan perspektif teori fungsional yang mengutamakan keselarasan, 
keserasian dan kedamaian. Muara dari pemahaman kedua perspektif teori tersebut adalah kehidupan yang dinamis, sejahtera, damai, adil dan beradab melalui konvergensi komunikasi yang dialogis (Sumardjo, 2007). Titik temu tersebut, meminjam perpektif teori konflik, adalah dialog, yang proses komunikasi di dalamnya dipersyaratkan kesetaraan. Dialog merupakan muara teori komunikasi kontemporer yang dikemukan oleh Rogers dan Kinkaid (Sumardjo, 1999) yaitu model komunikasi relasional dengan paradigma utama konvergensi. Sumardjo dalam disertasinya membuktikan bahwa paradigma konvergensi dalam proses komunikasi pembangunan baik pada tataran makro maupun mikro terbukti efektif mengembangkan kemandirian petani dan pada gilirannya meningkatkan partisipasi masyarakat dalam mewujudkan kesejahteraan keluarga dan masyarakatnya. Hasil analisis atas situasi kehidupan di Nusantara disajikan dalam bentuk gambaran secara ringkas dapat dilihat pada Tabel 2 .

Potensi konflik dan akar permasalahan yang telah diungkap pada Tabel 1 ditindaklanjuti dengan upaya mencari alternatif solusi oleh masyarakat maupun dunia pendidikan seperti yang dituangkan pada Tabel 2. Dalam perspektif akademis, upaya mewujudkan kedamaian seyogyanya dapat ditempuh melalui model-model komunikasi yang tepat pada masing-masing tataran. Komunikasi yang sifatnya dialogis banyak mewarnai model-model komunikasi antar budaya, baik pada tataran interaksi antar bangsa melalui model-model intercultural communication, interaksi antar budaya melalui model crosscultural communication, maupun antar sub kultur melalui model intracultural communication, dan model organizational communication (Eilers, 1987; Irwin, 1996; Beamer, 2001; Jansen, 2002; dan Gudykunst, 2003). Hal ini menjadi pertimbangan penting bahwa dalam program studi Komunikasi Pembangunan Sekolah Pascasarjana di IPB permasalahan semacam ini menjadi kajian intensif di antara para mahasiswa dalam satu matakuliah Komunikasi Lintas Budaya dan Manajemen Konflik, yang dalam realita menjadi kebutuhan masyarakat dalam mewujudkan kedamaian dinamis berupa kesejahteraan yang adil dan bermartabat.

Pada tataran kehidupan masyarakat peran keluarga dan organisasi sosial sangat dibutuhkan melalui pendekatan-pendekatan yang tepat sesuai dengan alternatif resolusi konflik atau tepatnya pendekatan pengelolaan potensi konflik seperti yang telah disajikan pada Tabel 2. Dapat disebutkan disini pendekatan-pendekatan baik yang sifatnya organisasional maupun pendekatan keluarga seperti: (1) kontrol terhadap fungsi media melalui komisi siaran dan lembaga terkait seperti lembaga konsumen; (2) sosialisasi nilai utama kedamaian dalam keluarga, seperti etos kerja, kerjasama, kolaborasi, kemitraan, gotong royong, adaptif dsb; (3) pengembangan budaya organisasi yang merupakan kolaborasi nilai-nilai unggul kedamaian dan nilai kompetisi yang saling memperkuat seperti kemitraan; serta (4) Integrasi struktur organisasi yang mengutamakan nilai-nilai keunggulan seimbang dengan keadilan dan transparasi. 
Tabel 2 Peran Masyarakat dalam Upaya Mewujudkan Kedamaian

\begin{tabular}{|c|c|c|}
\hline \multirow{2}{*}{$\begin{array}{l}\text { Resolusi Konflik } \\
\text { (Kedamaian) }\end{array}$} & \multicolumn{2}{|c|}{ Peran Masyarakat } \\
\hline & Keluarga & Organisasi \\
\hline Toleransi/ akulturasi/ asimilasi & $\begin{array}{l}\text { Kontrol terhadap fungsi } \\
\text { Media }\end{array}$ & $\begin{array}{l}\text { Fasilitasi Hubungan } \\
\text { internasional }\end{array}$ \\
\hline $\begin{array}{l}\text { Komunikasi antar budaya } \\
\text {-akulturasi dan asimilasi }\end{array}$ & Sosialisasi nilai & Enkulturasi Budaya \\
\hline Kemitraan Kolaborasi & Pendidikan Etos kerja & $\begin{array}{l}\text { Sanksi (reward/ } \\
\text { punisment) }\end{array}$ \\
\hline Kemitraan/ Koordinasi & Fasilitasi pendidikan & $\begin{array}{l}\text { Diferensiasi peran } \\
\text { Formalisasi Struktur }\end{array}$ \\
\hline Kemitraan/ Sinkronisasi & Proses Adaptasi & $\begin{array}{l}\text { Integrasi budaya dan } \\
\text { struktur sosial }\end{array}$ \\
\hline
\end{tabular}

\section{Pengalaman Pengelolaan Media Komunikasi bagi Upaya Kedamaian}

Realitas kekinian dalam sistem komunikasi dihadapkan pada keragaman-keragaman terkait dengan peran media komunikasi dalam proses integrasi sosial menuju keharmonisan yang dinamis, yaitu: akses teknologi konvergensi, cakupan akses (coverage), keragaman kultur, level kompetensi masyarakat, dan tingkat kepastian hukum. Keragaman tersebut berpotensi menimbulkan kesenjangan-kesenjangan dalam tingkat kapasitas masyarakat yang bersumber dari keragaman-keragaman yang berpotensi menjadi sumber konflik sosial atau melemahkan kedamaian, yaitu keragaman-keragaman dalam hal : (a) tingkat pendidikan yang berdampak pada keragaman tingkat kompetensi, (b) tingkat kebutuhan/selera masyarakat yang berdampak pada motivasi atau minat berkomunikasi, (c) tingkat kemampuan yang berdampak pada intensitas akses inovasi aktual, serta, (d) kedudukan sosial yang berdampak pada keragaman hak dan kewenangan seseorang dalam masyarakat, dan keragaman aspek lainnya.

Peran perguruan tinggi adalah menyelenggarakan proses pendidikan formal maupun non formal melalui proses komunikasi konvergen dengan menggunakan media yang tepat dalam proses mewujudkan kesejahteraan masyarakat. Pada awal tahun 1980an sampai menjelang tahun 1990an, Bagian Penyuluhan dan Pembangunan Pedesaan, Departemen Ilmu-ilmu Sosial Ekonomi Pertanian mengkoordinir pelaksanaan Dewan Pembina Siaran Pedesaan (DPSP) bekerjasama dengan RRI Bogor. Pendekatan "taylor made message" yaitu penyiaran sesuai dengan kebutuhan dan waktu luang aksesibiltas masyarakat terhadap acara siaran pedesaan. Masingmasing Dinas dan instansi terkait secara bergantian dijadwalkan secara teratur pada hari, waktu dan gelombang yang sama, yang sesuai kondisi masyarakat menyampaikan pesan-pesan pembangunan. Pendekatan seperti ini dapat mencegah kesenjangan informasi yang dapat berpotensi sebagai sumber konflik sosial. Konsep penyiaran disempurnakan dengan berdasarkan hasil evaluasi siaran pedesaan yang didukung oleh dana dari Departemen Pendidikan dan Kebudayaan, sehingga keberlanjutannya cenderung menjadi semakin efektif.

Kemudian pada awal tahun 1990an, Fakultas Pertanian IPB menyelenggarakan sendiri kegiatan siaran dan meneruskan acara siaran yang serupa, namun meski belum dievaluasi secara khusus, namun dapat dicatat bahwa upaya pengelolaan 
media siaran tersebut dihadapkan pada kendala-kendala : selain biaya terbatas yang berdampak pada sulitnya mempertahankan kesinambungan siaran pedesaan semacam itu, ternyata masalah keterbatasan jangkauan siaran menjadi kendala tersendiri. Kemudian pada Tahun 2000 meskipun kegiatan siaran tersebut masih berlangsung, namun di samping daya jangkau yang terbatas dan dihadapkan pada kelemahan biaya, ternyata juga kurang dapat memanfaatkan kerjasama antar instansi seperti pada masa DPSP diselenggarakan. Dari pengalaman ini dapat dilakukan perbaikan ke depan untuk meningkatkan daya jangkau (coverage) dan menerapkan metoda taylor made message, khususnya 14 desa lingkar kampus yang menjadi mitra IPB untuk menjadi model interaksi sosial sinergis dan kolaboratif antara kampus perguruan tinggi dengan lingkungan masyarakat di sekitarnya.

Menghadapi berbagai keterbatasan tersebut peran media yang dikelola oleh sebuah perguruan tinggi hanya terbatas pada sasaran lingkungan terbatas sekitar kampus yang terutama adalah mahasiswa. Acara-acara diselenggaran dengan tujuan memenuhi kebutuhan informasi dengan sasaran utama mahasiswa, yaitu hal-hal yang terkait dengan substansi belajar dan kegiatan-kegiatan praktek untuk mahasiswa dalam bidang penyiaran melalui Radio. Hal ini berarti kemanfaatan atau peran media siaran menjadi sangat terbatas daya jangkaunya.

Berdasarkan pengalaman mengembangkan model pemberdayaan masyarakat pesisir ditemukan beberapa potensi konflik (Prastowo et al, 2009), antara lain bersumber pada : (1) persaingan antara nelayan kecil dan besar dalam mengakses dan meraih sumberdaya alam ikan di laut, (2) keterbatasan informasi pada para nelayan dalam pengelolaan sumberdaya keluarga, khususnya keuangan untuk konsumsi dan permodalan usaha nelayan, dan (3) akses terhadap pengembangan usaha alat tangkap dan perahu nelayan, serta (4) inovasi teknologi sarana dan prasarana alat tangkap. IPB melalui kerjasama kemitraan dengan pihak swasta dan masyarakat berencana mengembangkan radio komunitas untuk mengatasi masalah potensi konflik tersebut, dengan konsep sebagai berikut. Radio komunitas menyiarkan hiburan dan informasi yang dapat menghibur smbil menyebarluaskan informasi dan pengetahuan bagi nelayan dimana potensi ikan sedang berada pada saat nelayan melaut, sehingga nelayan tidak perlu membuang waktu dan energi untuk mendapatkan hasil tangkapan yang memadai. Informasi tentang keberadaan kumpulan ikan membuat nelayan tidak harus berkeliaran kemana-mana tetapi dapat menjadi lebih fokus ke lokasi sasaran penangkapan yang berpotensi banyak ikan tersebut. Selain itu juga informasi maupun inovasi yang benar-benar dibutuhkan oleh para nelayan khususnya dan masyarakat pesisir umumnya, misalnya informasi tentang pemanfaatan limbah ikan yang sebenarnya masih dapat digunakan atau teknologi pemisahan tulang dengan daging ikan seperti yang ditemukan oleh Prof Ari Purayanto seorang Guru Besar Fakultas Perikanan dan Kelautan IPB, sehingga nilai tambah nelayan dapat lebih ditingkatkan.

Peran perguruan tinggi terkait dengan pengelolaan media ini adalah secara partisipatif pengembangan kelembagaan media komunikasi siaran radio komunitas, dengan memanfaatkan ketertarikan generasi muda untuk menguasai teknologi media siaran, sekaligus menumbuhkan cinta bahari pada generasi muda yang sudah banyak luntur dan melemah. Lembaga atau unit kerja dalam lingkup Lembaga Penelitian dan Pengabdian Masyarakat dapat memanfaatkan media siaran ini sebagai media 
diseminasi informasi dan inovasi bagi upaya peningkatan kesejahteraan masyarakat. Kemerataan akses informasi berpeluang memperkecil kesenjangan antar lapisan dan antar strata nelayan dan pergusaha penangkapan ikan lainnya, sehingga potensi persaingan dan konflik dapat dikelola sampai pada taraf moderat, yaitu situasi harmoni dan dinamika sosial terjadi dalam iklim kedamian masyarakat.

\section{Peranan Peranan Perguruan Tinggi dalam Upaya Mewujudkan Kehidupan Damai}

Melalui media komunikasi yang tepat perguruan tinggi berpotensi mempunyai banyak peran untuk mengembangkan dinamika harmoni kehidupan masyarakat. Mewujudkan konflik, persaingan dan kontravensi di antara masyarakat menjadi dinamika harmoni, melalui proses dialogis dan komunikati relasional yang konvergen dengan menggunakan media radio komunitas maupun media tradional yang ada kedalam media modern siaran radio. Misalnya cerita "paso sore" atau wayang yang merupakan media tradisional dapat disiarkan melalui acara dengan media siaran radio. Bahkan ke depan tidak menutup kemungkinan siaran televisi daerah juga dapat dikembangkan menjadi teknologi media komunikasi konvergen yang manakala eranya sudah kondusif. Saat ini radio masih lebih terjangkau dan dapat dibawa ke tempat kerja atau tempat usaha nelayan atau petani.

Peran perguruan tinggi yang utama adalah menggali dan mengembangkan nilai-nilai budaya yang unggul dalam kehidupan masyarakat melalui pendidikan bagi mahasiswanya maupun kiprah tenaga pendidik maupun tenaga kependidikan dalam kehidupan akademis maupun dalam praktek magang atau kuliah kerja nyata di masyarakat. Melalui mahasiswa dapat ditempuh melalui jalur kurikuler dan silabus bagi proses pembelajaran di kampus, maupun kebijakan dan implementasinya dalam kegiatan co kurikuler dalam mengembangkan softskill mahasiswa sebagai kader kepemimpinan bangsa. Gambaran peran perguruan tinggi secara singkat disajikan pada Tabel 3

Dalam kurikulum dinilai perlu diwarnai substansi teori komunikasi antar budaya atau komunikasi interkultural (Beamer, 2001; Gudykunst, 1993; Gudykunst, 2003) dan wawasan paradigma dominan teori fungsional dan teori konflik dalam proses pembelajaran di bangku kuliah. Dengan demikian mahasiswa tidak terjebak pada suatu pemikiran sempit aliran pemikiran tertentu maupun intervensi indoktrinatif oleh kepentingan pihak-pihak tertentu di luar kampus. Intinya adalah mengembangkan filter system pada mahasiswa sehingga secara sistematis menjadi daya tahan diri dalam kehidupan yang lebih luas pada tataran masyarakat, berbangsa maupun antar bangsa. Di samping pengembangan hardskill, tampaknya pengembangan kapasitas kehidupan berbangsa (Nation Building) menjadi keharusan, agar mahasiswa tidak terjebak pada moral hazard dalam kehidupan dan dalam pengembangan karirnya setelah lulus maupun dalam kehidupan semasa mengikuti proses pendidikannya.

Memperhatikan keluhan para alumni yang bekerja di lingkungan BUMN, khususnya di perkebunan maupun di organisasi bisnis/perusahaan yang dinyatakan bahwa kelemahan yang utama dari lulusan erguruan tinggi adalah dalam hal softskill. Fenomena tersebut tidak hanya ditemukan pada lulusan perguruan tinggi swasta bahkan pada perguruan tinggi negeri yang terkenal pun masih sering ditemukan. Kompetensi hardskill merupakan suatu keharusan, namun tidak cukup memadai 
untuk membangun suatu karir dan kelembagaan yang kokoh dalam era komptetisi global ini.

Tabel 3 Peran Pendidikan Tinggi dalam Upaya Mewujudkan Kedamaian

\begin{tabular}{|l|l|l|}
\hline \multirow{2}{*}{$\begin{array}{l}\text { Resolusi Konflik } \\
\text { Kedamaian) }\end{array}$} & \multicolumn{2}{|c|}{ Peran Perguruan Tinggi } \\
\cline { 2 - 3 } $\begin{array}{l}\text { Toleransi/ } \\
\text { akulturasi/ asimilasi }\end{array}$ & $\begin{array}{l}\text { Intercultural communication : } \\
\text { proses Interaksi dengan beda } \\
\text { budaya }\end{array}$ & $\begin{array}{l}\text { Integrasi HAM : Pertukaran } \\
\text { Budaya/ mahasiswa; Asrama } \\
\text { internasional dsb }\end{array}$ \\
\hline $\begin{array}{l}\text { Komunikasi antar } \\
\text { budaya } \\
\text {-akulturasi } \\
\text {-asimilasi }\end{array}$ & $\begin{array}{l}\text { Crosscultural communication: } \\
\text { Membandingkan dengan budaya } \\
\text { lain }\end{array}$ & $\begin{array}{l}\text { Pendidikan kebangsaan: } \\
\text { Kepramukaan, SAR, Menwa, } \\
\text { Kepemimpinan, Softskill, } \\
\text { Asrama multi budaya, Etika } \\
\text { Kehidupan kampus yang netral } \\
\text { dsb }\end{array}$ \\
\hline $\begin{array}{l}\text { Kemitraan } \\
\text { Kolaborasi }\end{array}$ & $\begin{array}{l}\text { Intracultural communication: } \\
\text { yang terjadi dalam satu budaya } \\
\text { sehingga dalam satu budaya } \\
\text { terdapat subkultur-subkultur }\end{array}$ & $\begin{array}{l}\text { Pengembangan solidaritas } \\
\text { sosial : kompetisi prestasi, } \\
\text { ekspresi potensi kerjasama, } \\
\text { Kuliah kerja profesi/ KKN } \\
\text { Dsb }\end{array}$ \\
& Komunikasi Organisasi & $\begin{array}{l}\text { Kebijakan Organisasi } \\
\text { kemahasiswaan; sertifikasi } \\
\text { profesi dsb }\end{array}$ \\
\hline $\begin{array}{l}\text { Kemitraan } \\
\text { koordinasi }\end{array}$ & & $\begin{array}{l}\text { Kebijakan kehidupan kampus } \\
\text { netral dari intervensi golongan } \\
\text { di luar sistem pendidikan } \\
\text { tinggi. }\end{array}$ \\
\hline $\begin{array}{l}\text { Kemitraan/ } \\
\text { Sinkronisasi/ } \\
\text { Integrasi Bangsa- } \\
\text { budaya }\end{array}$ & Wawasan Keadilan/ HAM &
\end{tabular}

Di balik kompetisi yang gencar diantara perguruan tinggi terkemuka dalam meraih kualitas, kini masih banyak ditemukan perguruan tinggi yang orientasi kualitasnya masih kurang memadai. Keadaan ini mendapat tempat yang luas bagi kalangan masyarakat bahkan birokrasi yang orientasinya bukan kompetensi melainkan ijazah atau sertifikat. Sertifikat pendidikan perguruan tinggi menjadi sekedar simbol untuk meraih kedudukan dalam birokrasi atau status dalam masyarakat, namun tidak disertai kompetensi yang memadai. Hal ini menjadi tanggungjawab bersama dalam mengembangkan dunia pendidikan tinggi.

Implikasi atas hal ini adalah perlunya dikembangkan sertifikasi profesi bagi lulusan perguruan tinggi agar lulusan perguruan tinggi dijamin kompetensinya. Perguruan tinggi dapat menjadi inisiator sekaligus wadah pengembangan tempat uji kompetensi profesi semacam itu. Kesenjangan atas kompetensi profesi ini menyebabkan penghargaan dan kompetisi tenaga lulusan perguruan tinggi menjadi lemah, sehingga sudah saatnya dikembangkan Lembaga Sertifikasi Profesi dan Lemaga Asosiasi Profesi yang menjamin dan memelihara kompetensi profesi seseorang lulusan perguruan tinggi. 


\section{Penutup}

Kedamaian seyogyanya diwujudkan melalui kesadaran dan pemahaman atas akar permasalahan dan alternatif solusi permasalahan yang menjadi kendala terwujudnya kedamaian tersebut. Keragaman etnis, kepercayaan, golongan, rofesi, strata dan kepentingan lainnya berpotensi menjadi sumber konflik yang menghambat terwujudnya kedamaian. Dalam kedamaian mengandung unsur kesiapsiagaan (readiness), kompeten, adil, dinamis, rukun, aman, dan mandiri. Tanpa unsur-unsur tersebut maka kedamaian adalah semu dan lebih bersifat dominasi yang dibungkus dengan upaya sistematis dalam mempertahankan sistem yang menindas melalui pendidikan. Upaya mewujudkan kedamaian dalam kehidupan diri, bermasyarakat dan berbangsa perlu upaya kolaboratif antara masyarakat dan dunia pendidikan formal, khususnya pendidikan tinggi.

Pemanfaatan media komunikasi yang tepat berpotensi menjadi media untuk mengembangkan dinamika keharmonisan melalui pengelolaan potensi konflik, kontravensi, dan persaingan. Konflik baik di tingkat keluarga, kelompok, organisasi maupun masyarakat tidak jarang terjadi disebabkan oleh kesenjangan informasi akibat kebuntuan dalam komunikasi. Perguruan tinggi berpotensi kuat menjadi agen pengembangan dan diseminasi informasi dan ilmu pengetahuan dan teknologi, serta seni budaya hasil-hasil penelitian, namun pada saat ini potensi tersebut belum tergali dan belum dikembangkan secara memadai, atau bahkan terkesampingkan. Tenaga perguruan tinggi relatif kompeten dalam pembelajaran (pendidikan) dan penelitian, namun kompetensi untuk penyuluhan atau pengembangan masyarakat relatif belum memadai. Tridharma perguruan tinggi menjadi kurang terimplementasi secara memadai manakala tenaga yang berkompetensi atau berkemampuan dalam bidang penyuluhan atau pengabdian masyarakat tidak dikembangkan secara memadai.

Peran perguruan tinggi adalah menggali dan mengembangkan nilai-nilai unggul dari kerifan lokal secara dinamis dalam tata kehidupan yang lebih luas dan mengembangkan nilai-nilai tersebut dalam ranah kurikuler maupun kegiatan non kurikuler secara tersistem dan dinamis. Disadari pada saat ini masih belum jelas nilai-nilai ideal dan nilai-nilai aktual yang menjadi pegangan dalam pendidikan berbangsa menuju kedamaian yang dinamis tersebut, seperti yang terjadi di Korea seperti "samuael undong" maupun di Jepang dan Cina yang berkembang pesat dengan basis nilai-nilai kerifan lokal kebangsaannya. Hal ini semestinya menjadi salah satu tanggungjawab utama pendidikan tinggi di Nusantara ini.

\section{Daftar Rujukan}

Beamer, Linda. 2001. Intercultural Communication in The Global Workplace. Mc Graw Hill-New York.

Covey, Stephen R. 1993. The Seven Habit of Highly Effective People. Simons \& Schuster Inc.

Eilers, Josef and Franz. 1987. Communicating Between Cultures - An Introduction to Intercultural Communication. Divine Word Publication. Manila.

Fathy Yousef, John C. Condon. 1983. An Introduction to Intercultural Communication. The Bobbs Merrill Company, Inc. Indianapolis-Indiana. 
Gray, Barbara. 1989. Collaborating : Finding Common Ground for Multiparty Problems. San Francisco: Jossey-Bass Publisher.

Gudykunst, William B. 1993. Intercultural Communication Theory - Current Perspectives. Sage Publication. Beverly Hills.

2003. Cross-Cultural Communication and Intercultural Communication. Sage Publications. Thousand Oaks, London.

Henslin, James M. 2007. Sociology: A to Down Earth Approach. Eightth Edition. Southtern Illinois University Edwardsvile. Pearson. Boston etc.

Irwin, Harry. 1996. Communicating with Asia-Understanding People and Customs. Allen \& Unwin. Sidney, Australia.

Jansen, Sue Curry. 2002. Critical Communication Theory, Power, Media, Gender and Technology. Rowman. Littlefield Pub, Inc. New York.

Straus, David. 2002. How to Make Colaboration Work: Powerfull Way to Build Consensus, Solve Problems, and Make Decisions. San Francisco: BerretKoehler Publishers, Inc.

Sumardjo, Syamsudin E., Puji Mulyono dan Toha Nursalam. 2005. Kajian Kelompok Keagamaan Di Sebelas Perguruan Tinggi Negeri maupun Swasta. Kerjasama LP IPB dengan Departemen Agama RI. Bogor. 2005.

Sumardjo, Jaka Sulaksana, Wahyu Aris Darmono. 2004. Teori dan Praktik Kemitraan Agribisnis. Seri Agriwawasan. Panebar Swadaya. Jakarta.

Sumardjo. 1999. Transformasi Model Penyuluhan Pertanian Menuju Pengembangan Kemandirian Petani” Disertasi SPS IPB. Bogor.

Sumardjo. 2007. "Komunikasi dalam Perspektif Ekologi Manusia" dalam Adiwibowo, 2007. Ekologi Manusia. Fakultas Ekologi Manusia IPB. Bogor.

Sumardjo. 2008. "Penyuluhan Pembangunan Pilar Penopang Kemajuan dan Kemandirian Masyarakat". Dalam Ida Yustina dan Adjat Sudradjat, 2008. Pemberdayaan Manusia Pembangunan Bermartabat. Sydex Plus. Bogor.

Prastowo, Sumardjo, Pramono, dan Eko Sriwiyono. 2009. Model Pemberdayaan Masyarakat Pesisir di Desa Cikahuripan. LPPM IPB Bogor. 
